\title{
Research Trends on Socioscientific Issues: A Content Analysis of Publications in Selected Science Education Journals*
}

\author{
Nurcan Tekin ${ }^{1}$, Oktay Aslan $^{2}$, Suleyman Yilmaz ${ }^{1}$ \\ ${ }^{1}$ Aksaray University, Faculty of Education, Turkey \\ ${ }^{2}$ Necmettin Erbakan University, Ahmet Kelesoglu Faculty of Education, Turkey \\ Correspondence: Nurcan Tekin, Aksaray University, Faculty of Education, Turkey.
}

Received: April 25, 2016

doi:10.11114/jets.v4i9.1572
Online Published: May 23, 2016

URL: http://dx.doi.org/10.11114/jets.v4i9.1572

\begin{abstract}
Socioscientific issues (SSIs) have gained recently more importance in science education. SSIs are an important component of scientific literacy. SSIs are social dilemmas including conceptual or technological links to science. The present study aims to determine SSIs related research trends via content analyses of the articles published from 2004 to 2015 in five selected science education journals (SE, JRST, S\&E, IJSE and RSE). Therefore, first, five journals with the highest impact factor were selected. Then, SSIs related papers were determined using electronic database search and thus 122 SSIs related articles were analyzed to determine trends in timeline, research types, related research topics, and research sample groups. The results show that SSIs related articles increased steadily leading to a peak in 2012 with the highest publishing rate in IJSE. Most of the SSIs related research employed qualitative methods. The highest rate of SSIs related qualitative studies was determined in IJSE (50.00\%), and the lowest in S\&E (3.57\%). However quantitative methods were employed the least. In the relevant SSIs related research published about argumentation, decision-making, and informal reasoning were the most frequent SSIs related topics. The most studied research sample groups consisted of junior and senior high school students. Preschoolers were not among the sample groups. These findings indicate SSIs progressed throughout the years for paving the way for further SSIs related research studies.
\end{abstract}

Keywords: socioscientific issues, science education journals, content analysis

\section{Introduction}

In educational research, a process involving the analysis of data obtained from research processes and methods directed to the relevant field of education is adhered to (Mortimore, 2000). This type of research, gaining more and more importance in recent years, is employed to refine education policies, to form theoretical bases, and to develop necessary applications. These research are important for the revision of earlier research and for paving the way for future (Göktaş, Küçük, Aydemir, Telli, Arpacık, Yıldırım \& Reisoğlu, 2012). According to Mortimore (2000), one of the four functions of educational research is disseminating data about a topic studied and by means of these data to form a perspective for a current theory or theories still developing. Therefore, the examination of trends in educational research will lead scientists who are working in this field (Cohen, Manion \& Morrison, 2007).

Science and technology is one of the most important factors affecting our lives in all aspects. As a customer or as a decision-maker, individuals must know the limits and powers of science in order to lead a safer and happier live within the society (Ziman, 1980). Therefore, evaluating science education in terms of scientific literacy is necessary (Leite, 2002; National Research Council [NRC], 2000). Research in science education is especially based on information acquisition for defending an idea and on decision-making processes in educational activities from various perspectives (Bassey, 1995; as cited in Chang, Chang \& Tseng, 2010). This does not only enable students to succeed in science classes and to have efficient scientific literacy skills, but also to analyze the occurrence of past events and how these would direct the tendencies of further studies (Chang et al., 2010). Scientific literacy is also important for the development of discussion, interpretation, and interference skills (Sadler, 2004, Sadler \& Zeidler, 2005). Learning about SSIs including meta-strategic skills such judgment, decision-making or argumentation learning is important in this

\footnotetext{
*A part of the study was presented at the International Academic Conference on Teaching, Learning and E-Learning, held in Vienna, Austria, November 13-14, 2015.
} 
regard (Sakschewski, Eggert, Schneider \& Bögeholz, 2014). In the respect, SSIs come to the fore as an important constituent of scientific literacy skills (Kolstø, 2001, Sadler, 2004).

The most important connection of SSIs with science education is that it is within the content of Science-Technology-Society (STS) framework (Yager, 1996; as cited in Sadler, 2011). In the learning domain of Science-Technology-Society-Environment (STSE), SSIs provide individuals to develop alternative solutions and ethical and scientific reasoning skills (Ministry of National Education of Turkey [MoNE], 2013). These issues are social dilemmas that have conceptual or technological links to science (Sadler, 2004). SSIs are also related to society as they also contain ethical and moral dilemmas (Morris, 2014). Zeidler, Walker, Ackett \& Simmons (2002) define SSIs as a term containing all classifications made by STS while considering the ethical dimension of science moral reasoning as well as students' emotional development. SSIs are often issues appearing frequently in the media but do not have clear-cut answers. They consists of open-ended problems with incomplete scientific evidence including sustainable development and values (Ratcliffe \& Grace, 2003). These issues are related generally to people's daily life activities (Kolstø, 2001). These activities may include efficient energy usage (Acar, Turkmen \& Roychoudhury, 2010), global warming (Cook, 2012, Reis \& Galvão, 2009), nuclear/radioactive wastes (Morris, 2014; Lee, Abd-El-Khalick \& Choi, 2006; Tal, Kali, Magid \& Madhok, 2011) and stem cell (Levinson, 2008; Reis \& Galvão, 2009; Sadler, Chambers \& Zeidler, 2004; Shea, 2013) as well as gene therapy (Tal et al., 2011, Zohar \& Nemet, 2002). For example; Acar et al. (2010) suggest in their study on decision-making, nature of science, and argumentation that argumentation exercises should be definitely made. Hence, the arguments thus developed, will enable the students to defend their own ideas related to SSIs, evaluate different alternatives, and enable value-oriented decision-making in terms of intuitive education. Zohar \& Nemet (2002) in their study making argumentations on subjects including dilemma in the field of genetics, have reached the conclusion that the students' knowledge on biology as well as their reasoning ability had increased. According to Lee et al. (2006), Korean secondary school teachers have stated that SSIs are required in the science curriculum. Considering the importance of SSIs in science education and its relationship with other fields, analyzing the research topics in this field, the trends over the years, the variety of methods used, and the samples will provide guidance to the researchers in the field.

In the studies made, providing information about the tendencies and the status of previous studies will help researchers to perform further studies (Lee, Wu \&Tsai, 2009). There are various studies in the relevant literature in which content analyses have been made in science education. Generally, overall content analysis related to science education was performed (Cavas, 2015; Lee et al., 2009; Lin, Lin \& Tsai, 2014; Tsai \& Wen, 2005). In addition to these general analysis, there are specific studies using content analyses related to scientific literacy (Deboer, 2000), conceptions of nature of science (Lederman, 2007), attitudes towards science (Osborne, Simon \& Collins, 2003) the laboratory in science education (Hofstein \& Lunetta, 1982), argumentation (Erduran, Özdem \& Park, 2015). Among these studies, Cavas (2015) analyzed 126 articles published during 2011-2015 in Science Education International. On examining these studies according to their authors, articles are mostly from Turkey followed by USA and Australia. On examining these studies according to their topic, the focus is mostly on teacher education, teaching of concepts, and teaching of content. Furthermore the least studied topics were about the history, philosophy, epistemology, and nature of science and informal learning. In their study, Tsai \&Wen (2005), analyzed the articles published in the International Journal of Science Education, Science Education and Journal of Research in Science Teaching throughout1998-2002 and determined that the English-speaking countries such as US, UK, Australia, and Canada had relatively high contribution to the literature. When these journals were analyzed in terms of method, case studies, reviews, and theoretical studies were quite common. It is noteworthy that most of the articles had been categorized as experimental. According to their study, Lee et al. (2009), science educators were more interested in research topics about learning from 2003-2007. Moreover, they had changed slightly their research interest between 1998-2007, from 1998-2002 there was a tendency towards studies on students' conceptual learning and conceptual changes and from 2003-2007 a shift towards students' learning of content related subjects. In addition, argumentation has become remarkably important in the most cited studies of the past 15 years in science education. Lin et al. (2014) concluded that from 2008 to 2012, the most researched three areas were about learning of concepts, science education, and conceptual learning of students.

Recently, the most cited articles in science teaching are related with argumentation, inquiry-based learning, and scientific modeling. Furthermore, in the 2014 study of Topçu, Muğaloğlu \& Güven, dissertations and research articles about science education related SSIs issues in Turkey and their results were examined. This study shows that SSIs related studies Turkey focus on two roles of SSIs. Accordingly, in Turkey SSIs are used either as an aim or as a tool in the teaching environment. In these studies, pre-service science teachers' level of knowledge, self-efficacy beliefs about teaching and informal reasoning have been widely analyzed. Moreover, the presence of few qualitative studies is another interesting factor. 
Studies analyzed systematically will guide researchers in the preparation of future research (Tsai \& Wen, 2005). When the above-mentioned studies are examined; whereas there are content analyses in the field of education, no content analysis studies were seen about popular science education journals containing SSIs related science education articles. The analysis of the selected journals will contribute to the related literature by determining the tendency of SSIs related studies. A study of this genre about SSIs, among the hotly debated topics in science education is expected to form a perspective by providing a basis for those interested in science education.

The aim of the present study is to analyse the presence of SSIs related articles in five science education journals (Science Education [SE], Journal of Research in Science Teaching [JRST], Science and Education [S\&E], International Journal of Science Education [IJSE] and Research in Science Education [RSE]) during the 2004-2015 period. Hence, the present study aims to answer the following research questions:

1) How are the articles about SSIs published in the five selected journals distributed over the years and in the journals?

2) How are the articles about SSIs distributed according to their type of research in the selected five journals?

3) How are the articles about SSIs distributed according to SSIs related topics in the selected five journals?

4) How are the articles about SSIs distributed according to research sample groups in the selected five journals?

\section{Method}

This study is a content analysis of SSIs related articles in five science education journals published from 2004 to 2015 . Content analysis is a commonly used method in qualitative studies. The analysis approach preferred by the researchers varies according to the theoretical and substantive concern of the researchers and the specific problem being studied (Weber, 1990). In this study, the methodology was organized as follows:

\subsection{Selection of Research Papers Related to SSIs for Analyses}

The present study first collected all the papers published in SE, JRST, S\&E, IJSE and RSE from 2004 to 2015 as the preliminary samples. The rationale for the choice of these five journals is that they are the major journals that have high impact factors in science education research. In these samples, 'editorial', 'commentary' and 'responses' were manually excluded.

\subsection{Search through Electronic Database}

The research related to socioscientific issues was sorted out through electronic database search, where the criterion was to include the terms 'socio-scientific', 'socioscientific' and the stem 'socio'. A second step screening of the abstracts resulted in the exclusion of some of the articles because of the word 'socioscientific or socio-scientific' as these do not refer to the content of SSIs but are only used as a verb in a generic sense, for example 'are used argumentative socioscientific issues'. Therefore, at this step of the resent study irrelevant articles are eliminated. The other articles eliminated were those including the stem 'socio' since some papers include word of 'socioeconomics', 'sociocultural', etc. In total, as context, 122 SSIs related articles were analyzed.

\subsection{Research Criteria}

The articles chosen according to the above-mentioned procedure were evaluated according to the articles' publication times and journal (Erduran et al. 2015), research types (Zheng, 2015), related research topics, and research sample groups (Zheng, 2015).

\subsection{Validity and Reliability}

In order to ensure the validity and reliability of the content analysis, the coding scheme was developed considering steps in previous studies on journal content analysis. The scheme included: publication times and journal, research types, related research topics and research sample groups. In order to establish the reliability of the content analysis, initially two authors classified each research paper individually and then results compared with each other. The inconsistencies that were identified and the differences were settled through discussion.

\section{Findings and Results}

All published SSIs papers in SE, JRST, S\&E, IJSE and RSE, were analyzed according to time, research type, research topic, and sample groups throughout the time period of 2004-2015. In total, 122 papers were analyzed. The ratio of SSIs issues in the five selected journals between 2004 and 2015 are as follows: SE 15 (12.30\%), JRST 20 (16.39\%), S\&E 11 (9.02\%), IJSE 58 (47.54\%), and RSE 20 (16.39\%).

\subsection{Trends across Years and across Journals}

In order to identify trends in the SSIs according to time and journal, the number of SSIs articles published each year in each of the journals is presented in Figure 1. The number of article related to SSIs increased gradually year by year. 
According to Figure 1, there were seven articles (5.78\%) published in 2004, seven articles (5.78\%) in 2006, nine articles $(7.44 \%)$ in 2008 , nine articles $(7.44 \%)$ in 2010 , and finally this number reached 21 articles $(17.35 \%)$ in 2012 and 18 $(14.88 \%)$ articles in 2014 .

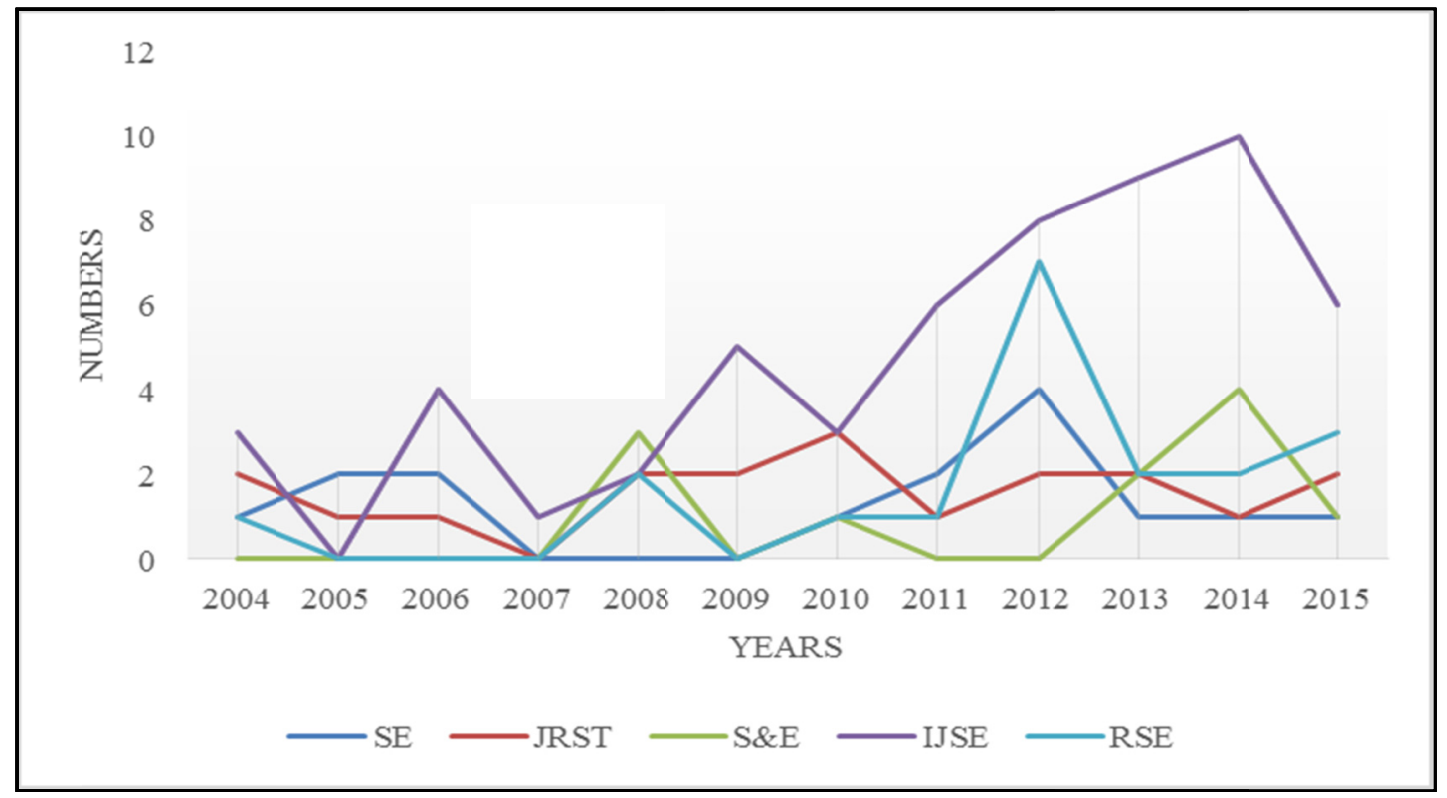

Figure 1. Number of SSIs articles published in SE, JRST, S\&E, IJSE and RSE from 2004 to 2015

The highest number of SSIs related articles was published, in 2012 (17.35\%) followed by 2014 (14.88\%), 2013 (13.22\%), and 2015 (10.74\%). In the last four years, the total number of SSIs related articles was 68 (55.73\%). However, the least number of articles was published in 2007 (0.83\%). This ratio can be attributed to the single article published in IJSE. The highest number of SSIs related articles was in IJSE (47.11\%) followed by JRST (15.70\%) and RSE (15.70\%) and the least in S\&E (9.10\%) over the 12 years.

\subsection{Trends Research Types}

SSIs articles determined beforehand in each of the journal were analyzed according to their research types (Figure 2).

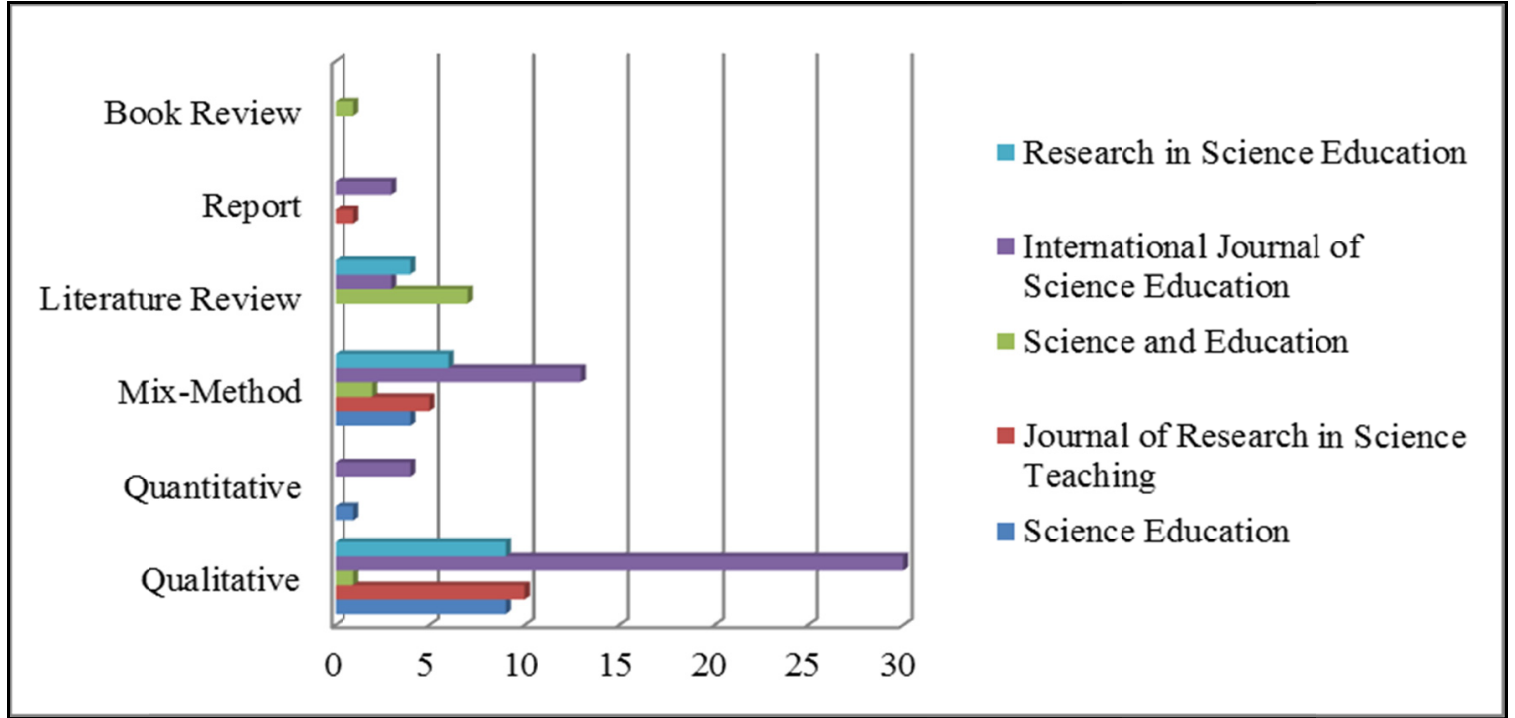

Figure 2. Number of SSIs related articles published in SE, JRST, S\&E, IJSE and RSE according to research types Qualitative methods of research were used mostly in SSIs related articles (53.85\%). In detail, qualitative methods were used at a high rate in IJSE $(50.00 \%)$ and the lowest rate in S\&E (3.57\%). However, the rate of quantitative methods usage was just $4.42 \%$ in the total of all journals. Moreover, SSIs related literature review (in RSE, IJSE and S\&E), report (in IJSE) and book review studies were also encountered in these five journals during the analysis period. 


\subsection{Trends Related Research Topics}

In order to identify trends in SSIs related research topics in the articles, the topics of the articles with earlier determined number in total is presented in Table 1.

Table 1. Number of SSIs articles published in SE, JRST, S\&E, IJSE and RSE according to related research topics

\begin{tabular}{|c|c|c|c|c|c|c|}
\hline Topics & \multicolumn{5}{|c|}{ Journals (N) } & $\mathbf{P}(\%)$ \\
\hline Argumentation & 2 & 7 & 1 & 14 & 2 & 19.55 \\
\hline Decision-making & 8 & 2 & 2 & 9 & 1 & 16.54 \\
\hline Informal reasoning & 2 & 4 & - & 7 & 2 & 11.28 \\
\hline Nature of science & - & 2 & 2 & 6 & 1 & 8.27 \\
\hline Scenario & 3 & 2 & - & 1 & - & 4.51 \\
\hline Epistemological view & 1 & 2 & - & 1 & 1 & 3.76 \\
\hline Sustainability & 1 & - & - & 1 & 4 & 4.51 \\
\hline Media & - & - & 1 & 2 & 2 & 3.76 \\
\hline Dilemma & 1 & 2 & - & - & 1 & 3.01 \\
\hline Conceptual studies & 1 & 2 & - & 2 & 2 & 5.26 \\
\hline Discussion & 1 & - & - & 2 & - & 2.26 \\
\hline Curriculum & - & - & - & 1 & 2 & 2.56 \\
\hline Classroom practices & - & - & - & - & 3 & 2.56 \\
\hline Citizenship & - & - & 2 & - & - & 1.50 \\
\hline ICT & - & - & - & 2 & - & 1.50 \\
\hline Other topics* & 1 & 1 & - & 6 & 4 & 8.27 \\
\hline $\mathbf{P}(\%)$ & 15.79 & 18.05 & 6.77 & 40.60 & 18.80 & 100 \\
\hline
\end{tabular}

*Other topics includes Deborah's dilemma, reflective reasoning, cognitive structures, learning strategies, cooperative learning, first language teaching, inquiry based teaching, textbook, teachers' professional development, emotions, hybridized writing, and critical reading.

According to Table 1, while the most SSIs related topics were published in IJSE (40.60\%), the least number of articles was published in S\&E (6.77\%). On the other hand, $19.55 \%$ of the studies were about argumentation, $16.54 \%$ were about decision-making, and $11.28 \%$ about informal reasoning. The percentage of articles published about Deborah's dilemma, reflective reasoning, cognitive structures, learning strategies, cooperative learning, first language teaching, inquiry based teaching, textbook, teachers' professional development, emotions, hybridized writing, and critical reading was quite low. These topics were published only once in the five selected journals during the analysis period.

\subsection{Trends Research Sample Groups}

In order to show the SSIs articles according to the research sample groups, SSIs articles determined were studied in each of the journals according to the different research sample groups (Figure 3).

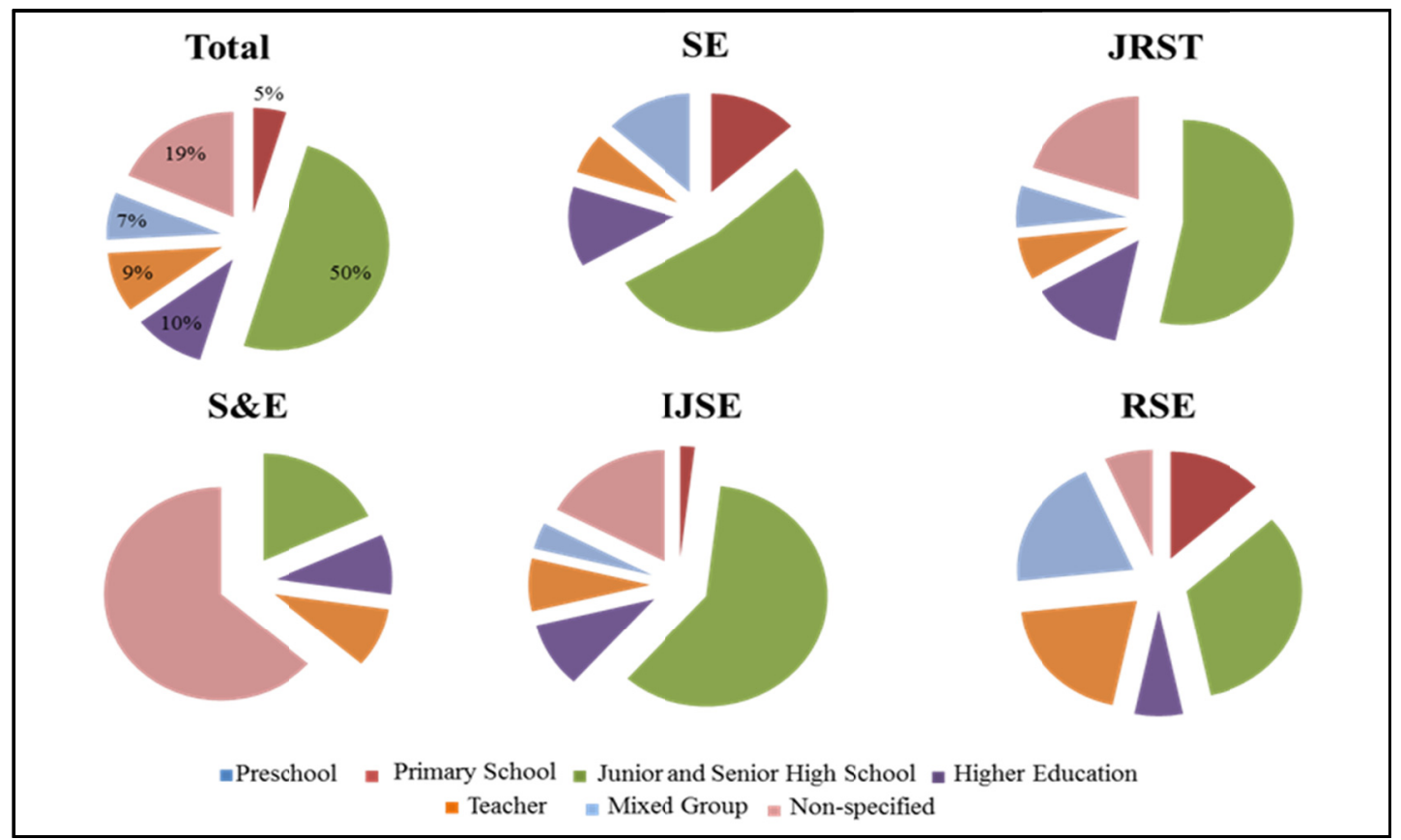

Figure 3. Number of SSIs articles published in SE, JRST, S\&E, IJSE and RSE according to research sample groups 
According to Figure 3, in all journals the sample of study in the SSIs related articles consisted of middle and high school students $(50 \%)$ and it is followed by college students $(10 \%)$. Although there are no SSIs related articles about pre-schoolers, the least number of studies conducted was with elementary school pupils (5\%). On the other hand, when the journals are examined in themselves; in S\&E the ratio of non -specified work is very high $(63.64 \%)$. There are no articles with mixed working groups. Both in JRST and S\&E there are no articles about elementary school pupils.

\section{Discussions}

On examining SSIs related articles, 122 in total, in the SE, JRST, S\&E, IJSE, and RSE journals published between 2004 and 2015, were analyzed. The maximum numbers of articles were published in IJSE. IJSE has yearly 18 issues with approximately eight articles in each issue. JRST and RSE were the second journals containing the most SSIs related publications. JRST has annually ten issues with approximately five articles in each issue and RSE has five issues with approximately seven articles. This might be the underlying reason why the highest numbers of SSIs related articles were published in IJSE.

Although SSIs related articles have been increasing steadily each year, the total number of the articles published in the last four years was half of the total number of articles in the past 12 years. In their study about argumentation related articles in three selected journals from 1998 to 2014, Erduran et al. (2015) reached the conclusion that the highest numbers of argumentation related articles were present within the last eight year period. According to them, one of the reasons for the presence of numerous articles in recent years is the use of argumentation in informal reasoning models within the socioscientific decision making process. According to Yager (1996, as cited in Sadler, 2011) SSIs have lately become one of the most focused issues because of their connection with STSE. In this sense, the trend related to SSIs is increasing. The increasing importance attributed to SSIs in the curriculum (American Association for the Advancement of Science [AAAS], 2000; Council of Ministers of Education, Canada [CMEC], 1997; Curriculum Council of Western Australia, 1998; MoNE, 2013) or in the science reform documents (NGSS Lead States, 2013; Dawson \&Venville, 2009), could be the reason for the significant increase of SSIs related articles in these journals.

In half of the SSIs related studies made between 2004 and 2015, qualitative research methods were employed. Quantitative analysis methods are used at least in SSIs related studies and in JRST. In S\&E and RSE, there are no SSIs related articles throughout these years using quantitative analysis methods. Despite the frequent report of experimental studies conducted as a result of contents analyses (Chiu, Tam \& Yen, 2016; Tsai \& Wen, 2005; Lee et al., 2009), there are also reports about a tendency in favor of quantitative research methods in science education (Zheng, 2015). Quantitative researches rarely focus on ethical of moral issues (Witz \& McGregor, 2003). As studies on SSIs have also an ethical and moral dimension (MoNE, 2013; Morris, 2015; Rundgren \& Rundgren, 2010; Sadler, 2011; Sadler \& Zeidler, 2004), there might be a divergence away from quantitative studies by the researchers. The most SSI related studied topics are argumentation, decision-making, and informal reasoning. According to Lin et al. (2014) from 1998 to 2012 in science education, the main focus is on argumentation among the SSIs. Argumentation and informal reasoning have become the most emphasized issues within the last 15 years. According to Driver, Asoko, Leach, Mortimer \& Scott (1994), science education not only has to enable knowledge acquisition about the natural world, but also acquisition of scientific methods of learning and learning of practices recognized by scientific communities. These practices include forming claims-hypotheses and using argumentation in order to bring clarity to such hypotheses and claims (Andrews, Castellon \& Clarke, 1993). Due to the widespread use of argumentation in teaching SSIs, studies associated with argumentation in SSIs related studies are the most common.

It is noteworthy that among the recent rapidly trending topics, inquiry based teaching and professional development of teachers are among the least studied themes. According to Lin et al. (2014) the term scientific inquiry has been an effective research focus in science education in the 2008-2012 period. Similarly, Chang et al. (2010) have shown in their study that among the most featured in science education from 1990-2007, professional development was among the most prevalent nine issues. Therefore, further study of SSIs related topics after these years would continue in terms of science education studies.

On the other hand, we estimate that the term 'education of sustainable development' will gain more importance in socioscience because of their social aspect. For example, in their study about students' socioscientific reasoning and decision-making on energy-related issues, Sakschewski et al. (2014) suggested that if we need energy-literate citizens who are socially critical and also decision-makers, we need to teach energy for sustainability. Thus, when sustainable development is considered to be interrelated with socioscientific issues, it would be fruitful in terms of citizenship.

In the journals analyzed, half of the study sample is SSIs articles consisted of middle and high school students. College students were ranking as the second. However, there were no studies made with preschoolers. Likewise, Zheng (2015) also concluded that studies made with middle and high school students was continually increasing but the number of studies made with preschoolers were at a minimum. SSIs contain reasoning, decision making or argumentation (Zeidler 
et al, 2002; Zohar \& Nemet, 2002). As the acquisition of these meta-strategic skills is quite difficult (Sakschewski et al., 2014), middle and high school students could be preferred.

In general, the recent increase in the trend of SSIs related research obtained as a conclusion of this study is considered to provide an important perspective for researchers or students bearing the intention to study SSIs and related subjects in near future. Awareness about the direction of the increasing trend in SSIs is expected to draw a path by facilitating current research and further studies.

In detail, the present study examining the content of SSIs related article is important, since it is first of its kind. Therefore, systematic analyses of SSIs related studies for the coming years could be suggested. Moreover, in addition to the SSIs related studies made in science education, content analyses (e.g. decision-making, informal reasoning, ethical or moral reasoning) of studies conducted in other fields could also be made. In the present study, only five journals with the highest impact factor were studied. Future content analysis studies made with journals in science education that include SSIs related articles would expand the framework and therefore worth endeavoring. Moreover, in this study the distribution of SSIs related articles according to years, method of research, related topics and research sample groups were also conducted by content analysis. Future research could include besides these information about authors, author specifications, and content knowledge used in the SSIs related articles.

\section{References}

Acar, O., Turkmen, L., \& Roychoudhury, A. (2010). Student difficulties in socio - scientific argumentation and decision - making research findings: Crossing the borders of two research lines, International Journal of Science Education, 32 (9), 1191-1206. http://dx.doi.org/10.1080/09500690902991805

American Association for the Advancement of Science (AAAS). (2000). Designs for Science Literacy. New York: Oxford University Press.

Andrews, R., Costello, P., \& Clarke, S. (1993). Improving the quality of argument: Final report. Hull, UK: University of Hull.

Cavas, B. (2015). Research trends in science education international: A content analysis for the last five years (2011-2015). Science Education International, 25(4), 573-588.

Chang, Y. H., Chang, C. Y., \& Tseng, Y. H. (2010). Trends of science education research: An automatic content analysis. Journal of Science Education and Technology, 19(4), 315-331. http://dx.doi.org/10.1007/s10956-009-9202-2

Chiu, M. H., Tam, H. P., \& Yen, M. H. (2016). Trends in science education research in Taiwan: A content analysis of the Chinese Journal of Science Education from 1993-2012. M. H. Chiu (Ed). Science Education Research and Practices in Taiwan: Challenges and Opportunities 43-78. Singapore: Springer.

Cohen, L., Manion, L., \& Morrison, K. (2007). Research methods in education. London: Routledge Falmer.

Cook, K. L. (2012). Can we really make a difference? Exploring pre-service teachers' experience with socio-scientific issues aiming for democratic participation in science. Doctor of Philosophy Thesis, Indiana University, Indiana.

Council of Ministers of Education, Canada. (1997). Common framework of science learning outcomes $K$ to 12 : Pan-Canadian protocol for collaboration on school curriculum for use by curriculum developers. Toronto, Canada.

Curriculum Council of Western Australia. (1998). The curriculum framework for kindergarten to Year 12 education in Western Australia. Perth, Western Australia.

Dawson, V., \& Venville, G. J. (2009). High-school students' informal reasoning and argumentation about biotechnology: An indicator of scientific literacy? International Journal of Science Education, 3(11), 1421-1445. http://dx.doi.org/10.1080/09500690801992870

DeBoer, G. E. (2000). Scientific Literacy: Another Look at Its Historical and Contemporary Meanings and Its Relationship to Science Education Reform. Journal of Research in Science Teaching, 37(6), 582-601. http://dx.doi.org/10.1002/1098-2736(200008)37:6<582::AID-TEA5>3.0.CO;2-L

Driver, R. H., Asoko, J., Leach, E., Mortimer, P., \& Scott, P. (1994). Constructing scientific knowledge in the classroom. Educational Researcher, 23(7), 5-12. http://dx.doi.org/10.3102/0013189X023007005

Erduran, S., Ozdem, Y., \& Park, J. Y. (2015). Research trends on argumentation in science education: a journal content analysis from 1998-2014. International Journal of STEM Education, 2(5), 1-12. http://dx.doi.org/10.1186/s40594-015-0020-1

Göktaş, Y., Küçük, S., Aydemir, M., Telli, E., Arpacık, Ö., Yıldırım, G., \& Reisoğlu, İ. (2012). Educational technology 
research trends in Turkey: A content analysis of the 2000-2009 decade. Educational Sciences: Theory \& Practice, 12 (1), 191-196.

Hofstein, A., \& Lunetta, V. (2004). The laboratory in science education: Foundations for the Twenty-First Century. Science Education, 88(1), 28-54. http://dx.doi.org/10.1002/sce.10106

Kolstø, S. D. (2001). Scientific literacy for citizenship: Tools for dealing with the science dimension of controversial SSI. Science Education, 85(3), 291-310. http://dx.doi.org/10.1002/sce.1011

Lederman, N. G. (2007). Nature of science: Past, present, and future. In S.K. Abell and N.G. Lederman (Eds.), Handbook of research on science education, 831-879. Mahwah, NJ: Lawrence Erlbaum Associates.

Lee, H., Abd-El-Khalick, F., \& Choi, K. (2006). Korean science teachers' perceptions of the introduction of socio scientific issues into the science curriculum, Canadian Journal of Science, Mathematics and Technology Education, 6(2), 97-117. http://dx.doi.org/10.1080/14926150609556691

Lee, M. H., Wu, Y. T., \& Tsai, C. C. (2009). Trends in science education from 2003 to 2007: A content analysis of publications in selected journals. International Journal of Science Education, 31(15), 1999-2020. http://dx.doi.org/10.1080/09500690802314876

Leite, L. (2002). History of Science in Science Education: Development and Validation of a Checklist for Analyzing the Historical Content of Science Textbooks. Science \& Education, 11(4), 333-359. http://dx.doi.org/10.1023/A:1016063432662

Levinson, R. (2008). Promoting the role of the personal narrative in teaching controversial socio-scientific issues. Science and Education, 17, 855-871. http://dx.doi.org/10.1007/s11191-007-9076-8

Lin, T. C., Lin, T. J., \& Tsai C. C. (2014). Research Trends in Science Education from 2008 to 2012: A systematic content analysis of publications in selected journals. International Journal of Science Education, 36(8), 1346-1372. http://dx.doi.org/10.1080/09500693.2013.864428

Ministry of National Education of Turkey (MoNE) (2013). İlköğretim Kurumları Fen Bilimleri Dersi Öğretim Programı [Elementary schools science education curriculum for grades 3, 4, 5, 6, 7, and 8] Ankara: Milli Eğitim Bakanlığı Talim ve Terbiye Kurulu Başkanlığı. Retrieved from http://ttkb.meb.gov.tr/

Morris, H. (2014). Socioscientific issues and multidisiplinarity in school science textbooks. International Journal of Science Education, 36 (7), 1137-1158. http://dx.doi.org/10.1080/09500693.2013.848493

Mortimore, P. (2000). Does educational research matter? British Educational Research Journal, $26(1), 5-24$. http://dx.doi.org/10.1080/014119200109480

National Research Council (NRC) (2000). Educating teachers of science, mathematics, and technology: new practice from the new millennium. Washington, DC: National Academy Press. Retrieved from: http://books.nap.edu/books/0309070333/html

NGSS Lead States (2013). Next generation science standards: For states, by states. Washington, DC: The National Academies Press.

Nielsen, J. A. (2011). Co-opting Science: A preliminary study of how students invoke science in value-laden discussions. International Journal of Science Education, 34(2), 275-299. http://dx.doi.org/10.1080/09500693.2011.572305

Osborne, J. F., Simon, S., \& Collins, S. (2003). Attitudes towards Science: A review of the literature and its implications. International Journal of Science Education, 25, 1049-1079. http://dx.doi.org/10.1080/0950069032000032199

Ratcliffe, M., \& Grace, M. (2003). Science education for citizenship: Teaching socio-scientific issues. Philadelphia: Open University Press.

Reis, P., \& Galvão, C. (2009). Teaching controversial socio-scientific issues in biology and geology classes: A case study. Electronic Journal of Science Education, 13(1), 1-24. Retrieved from: http://ejse.southwestern.edu/

Rundgren, S. C., \& Rundgren, C. J. (2010). SEE-SEP: From a separate to holistic view of socioscientific issues. Asia-Pacific Forum on Science Learning and Teaching, 11(1), 1-24.

Sadler, T. D. (2004). Informal reasoning regarding socioscientific issues: A critical review of research. Journal of Research in Science Teaching, 41 (5), 513-536. http://dx.doi.org/10.1002/tea.20009

Sadler, T. D. (2011). Socio-scientific issues-based education: What we know about science education in the context of SSI. T. D. Sadler (Ed). Socio-scientific Issues in the Classroom: Teaching, Learning and Research, 355-369. New York: Springer. http://dx.doi.org/10.1007/978-94-007-1159-4_20 
Sadler, T. D., \& Zeidler, D. L. (2005). Patterns of informal reasoning in the context of socioscientific decision making. Journal of Research in Science Teaching, 42(1), 112-138. http://dx.doi.org/10.1002/tea.20042

Sadler, T. D., Chambers, F. W., \& Zeidler, D. L. (2004). Student conceptualizations of the nature of science in response to a socioscientific issue. International Journal of Science Education, 26, 387-409. http://dx.doi.org/10.1080/0950069032000119456

Sakschewski, M., Eggert, S., Schneider, S., \& Bögeholz, S. (2014). Students' Socioscientific Reasoning and Decision-making on Energy-related Issues-Development of a measurement instrument. International Journal of Science Education, 36(14), 2291-2313. http://dx.doi.org/10.1080/09500693.2014.920550

Shea, N. A. (2013). Investigation the role of content knowledge, argumentation, and situational features to support genetics literacy. Doctor of Philosophy Dissertation, The State University of New Jersey, New Jersey.

Tal, T., Kali, Y., Magid, S., \& Madhok, J. J. (2011). Enhancing the authenticity of a web-based module for teaching simple inheritance. T. D. Sadler (Ed). Socio-scientific Issues in the Classroom: Teaching, Learning and Research 11-38. New York: Springer.

Topçu, M. S., Muğaloğlu, E. Z., \& Güven, D. (2014). Socioscientific issues in science education: The case of Turkey. Educational Sciences: Theory \& Practice, 14(6), 2327-2348.

Tsai, C. C., \& Wen, M. L. (2005). Research and trends in science education from 1998 to 2002: a content analysis of publication in selected journals. International Journal of Science Education, 27(1), 3-14. http://dx.doi.org/10.1080/0950069042000243727

Weber, R. P. (1990). Basic content analysis. Beverly Hills, CA: Sage.

Witz, K., \& MacGregor, N. (2003). Morality, Spirituality and Science in the Elementary Classroom. D. L. Zeidler (Ed). The Role of Moral Reasoning on Socioscientific Issues and Discourse in Science Education 165-182. Dordrecht: Kluwer Academic Publisher.

Zeidler, D., Walker, K., Ackett, W., \& Simmons, M. (2002). Tangled up in views: Beliefs in the nature of science and responses to socioscientific dilemmas. Science Education, 86(3), 343-367. http://dx.doi.org/10.1002/sce.10025

Zheng, L. (2015). A Systematic Literature Review of Design-based Research from 2004 to 2013. Journal Computers in Education, 2 (4), 399-420. http://dx.doi.org/10.1007/s40692-015-0036-z

Ziman, J. (1980), ). Teaching and Learning about Science and Society, Cambridge: Cambridge University Press. http://dx.doi.org/10.1017/CBO9780511896576

Zohar, A., \& Nemet, F. (2002). Fostering students' knowledge and argumentation skills through dilemmas in human genetics. Journal of Research in Science Teaching, 39, 35-62. http://dx.doi.org/10.1002/tea.10008 